\title{
Design of Infertility Monitoring System: Minimum Data Set Approach
}

\author{
Maryam Zahmatkeshan ${ }^{1,2}$, Mojtaba Farjam², Niloofar Mohammadzadeh', Tayebeh Noori', Zahra Karbasi', Zahra Mahmoudvand', \\ Majid Naghdi ${ }^{3}$, Reza Safdari ${ }^{1}$
}

1. Health Information Management Department, School of Allied Medical Sciences, Tehran University of Medical Sciences, Tehran, Iran

2. Noncommunicable Diseases Research Center, School of Medicine, Fasa University of Medical Sciences, Fasa, Iran

3. Department of Anatomical Sciences, School of Medicine, Fasa University of Medical Science, Fasa, Iran

\author{
Corresponding Authors: \\ Majid Naghdi \\ Department of Anatomical Sciences, School of Medicine \\ Fasa University of Medical Science, Fasa, Iran. \\ E-mail: majidnaghdi@yahoo.com \\ Reza Safdari \\ Health Information Management Department, School of Allied Medical Sciences, \\ Tehran University of Medical Sciences, Tehran, Iran. \\ E-mail: rsafdari@tums.ac.ir
}

Received: October 21st, 2018 - Accepted: January 5th, 2019

\begin{abstract}
Reproductive health is vital for human and infertility is also one of the most important challenges in the reproductive system. Infertility is one of the most common chronic health disorders, regardless of age. The Minimum Data Set (MDS) helps to manage infertility by monitoring and evaluating infertility interventions based on collecting data.

The development of MDS is an essential objective in order to implement an infertility monitoring system for the creation of standardized and effective data management through the provision of comprehensive and identical data elements for infertility.

This is a descriptive cross-sectional study conducted in 2017. The data has been collected from infertility clinics in the world, as well as WHO, CDC, ASRM, and ESHRE reports.

In order to decide on data elements, the Delphi technique was used using a questionnaire that contained data elements which were distributed among 12 experts including one reproductive endocrinology and infertility fellow, six obstetrician-gynecologists, two reproductive biologists, two urologists and one community medicine specialist using the 5 point Likert scale. The questionnaire was divided into two categories: managerial and clinical, each with 4 sections, and 60 and 940 data elements, respectively.

MDS is an essential tool for evaluating the infertility process. Using this tool will provide an opportunity to develop a set of quality care criteria that can be used to ensure the quality of infertility care.
\end{abstract}

Keywords: Data elements, Infertility, Minimum data set, Monitoring System

\section{Introduction}

One of the key issues is the global emphasis on public health policies and programs to increase the population and provide affordable, safe and well-planned and effective services for families [1]. According to statistics in 2010, 48.5 million couples were infertile in the world [2], and almost $10 \%$ of the world's population suffers from infertility [3]. In a survey of married women conducted by the Centers for Disease Control and Prevention (CDC) in 2015 in the United States, 1.5 million women (6\%) were infertile, and the number of women who have used infertility services so far has reached 7.4 million [4,5].

Infertility is one of the six maternal diseases/ consequences which has been neglected in developing countries [6]. Infertility has many side effects and is one of the causes of instability in the lives of couples [3, 4]. Infertility or its treatment can cause mental stress, anxiety, and depression [4]. Clinical depression in infertile women is similar to that of women with heart disease or cancer [3].

Therefore, in order to fully understand the effects of infertility and measure progress in reducing this problem and to cope with the growth management of data and information, attention to the collection, analysis, interpretation, and use of infertility data are of great importance [7]. Meanwhile, the most important step in managing information is to collect accurate and complete data and Minimum Data Set (MDS) is one of the most effective tools for collecting emerging data which provide accurate access to health information and as a set of 
information elements in health information systems, improves the use of high-quality data and it is very useful for planning, developing, monitoring, managing, and evaluating performances [4]. MDSs, by providing standard data with the same definitions, provide national and international comparisons [8] and as a basis for disease information management, improves the quality of care and disease control [9-12].

This is a descriptive cross-sectional study conducted in 2017. Information resources, including related articles, reports and forms related to infertility clinics and texts were searched using the following keywords: minimum data set, MDS, core data, infertility, infertility form, IVF registry, ART registry, surveillance system, monitoring system in the PubMed database, Scopus, Cochrane and WHO, CDC and Google scholar websites from 1978 to 2017. Collected data, according to the standards set of American National Standard Institute (ANSI), previous articles and references book were classified into managerial and clinical categories [17, 18, 24-26] and a questionnaire was created based on the 5-point Likert scale with 5 answer categories: strongly agree $=5$, agree $=4$, no idea $=3$, disagree $=2$, strongly disagree $=1$. At the end of each part, an empty row titled "Other Items" was considered for the addition of important data elements by experts. Content validity of the questionnaire was evaluated by 12 relevant experts from the University of Medical Sciences of Fasa, including one reproductive endocrinology and infertility fellow, six obstetrician-gynecologists, two reproductive biologists, two urologists and one community medicine specialist. Experts were asked to express their agreement with each of the elements based on the 5-point Likert scale. The acceptance criterion for the data elements in the final MDS was the level of agreement of the experts with a level of agreement of over $75 \%$ (score of 3.75 up to 5). Eventually, the final data elements of the MDS were obtained. The test-retest method was also used to ensure the reliability of the questionnaire. Thus, within 10 days, the experts were again asked to fill out the questionnaire for the second time. Spearman's rank correlation coefficient was $85 \%$ for the reliability of the questionnaire.

The purpose of this research is to develop the MDS required for a national infertility monitoring system in order to accelerate and facilitate the prevention, diagnosis, and follow-up of infertility.

This study is a research project as a part of the Maryam zahmatkeshan Ph.D. thesis approved by Tehran University of Medical Sciences. Also, the ethics committee of the university approved this study (IR.TUMS.SPH. REC.1396.4142). Verbal informed consent was obtained from all subjects before the study.

\section{Statistical analysis}

SPSS 16 software was used to analyze the data.

\section{Results}

Of the 12 experts, $75 \%$ were female, and $25 \%$ were male. Table 1 shows the demographic information and characteristics of the participating practitioners.

MDS was divided into two categories of managerial and clinical, each with 4 sections. The total number of final data elements in the managerial groups was 60 and 940 in the clinical groups. Table 2 shows the accepted data elements for managerial (section a) and clinical (section b) groups.

Examples of the managerial and clinical data elements that were accepted as the final set (over $75 \%$ ) are listed in Tables 3 and 4.

Table 1: Demographic characteristics of participants in the decision using the Delphi technique.

\begin{tabular}{|c|c|c|c|c|c|c|}
\hline Participants & Number & Gender & Age group & Education & Academic field & Experience (years) \\
\hline $\begin{array}{l}\text { Specialist of obstetrics and } \\
\text { gynecology }\end{array}$ & 7 & $\begin{array}{l}\text { Female: } 7 \\
\text { Male: } 0\end{array}$ & $\begin{array}{c}30-35: 3 \\
35-40: 2 \\
>40: 2\end{array}$ & $\begin{array}{l}\text { Fellowship of } \\
\text { reproductive } \\
\text { endocrinology } \\
\text { and infertility: } 1 \\
\text { Specialist: } 6\end{array}$ & $\begin{array}{l}\text { reproductive } \\
\text { endocrinology } \\
\text { and infertility, } \\
\text { obstetrics and } \\
\text { gynecology }\end{array}$ & $>5: 2$ \\
\hline reproductive biologists & 2 & $\begin{array}{l}\text { Female: } 1 \\
\text { Male: } 1\end{array}$ & $\begin{array}{c}30-35: 0 \\
35-40: 1 \\
>40: 1\end{array}$ & PhD: 2 & $\begin{array}{l}\text { reproductive } \\
\text { biology }\end{array}$ & $\begin{array}{l}<5: 0 \\
>5: 2\end{array}$ \\
\hline urologists & 2 & $\begin{array}{l}\text { Female: } 0 \\
\text { Male: } 2\end{array}$ & $\begin{array}{c}30-35: 1 \\
35-40: 0 \\
>40: 1\end{array}$ & Specialist: 2 & urology & $\begin{array}{l}<5: 0 \\
>5: 2\end{array}$ \\
\hline community medicine & 1 & $\begin{array}{l}\text { Female: } 1 \\
\text { Male: } 0\end{array}$ & $\begin{array}{c}30-35: 0 \\
35-40: 1 \\
>40: 0\end{array}$ & Specialist: 2 & $\begin{array}{l}\text { community } \\
\text { medicine }\end{array}$ & $\begin{array}{l}<5: 1 \\
>5: 0\end{array}$ \\
\hline
\end{tabular}


Table 2: Managerial and clinical data category for the Minimum Data Set for infertility

a) Managerial Data

$\begin{array}{lccccccc}\begin{array}{l}\text { Data } \\ \text { sections }\end{array} & \begin{array}{c}\text { Strongly Agree } \\ (\%)\end{array} & \begin{array}{c}\text { Agree } \\ (\%)\end{array} & \begin{array}{c}\text { No idea } \\ (\%)\end{array} & \begin{array}{c}\text { Disagree } \\ (\%)\end{array} & \begin{array}{c}\text { Strongly } \\ \text { Disagree (\%) }\end{array} & \begin{array}{c}\text { Average } \\ \text { rates }\end{array} & \begin{array}{c}\text { Final number of } \\ \text { data elements }\end{array} \\ \text { Demographic Data } & 78.9 & 12.3 & 5.3 & 1.3 & 0 & 4.6 & 38 \\ \begin{array}{l}\text { Insurance } \\ \text { information }\end{array} & 83.3 & 4.2 & 11.7 & 0.8 & 0 & 4.7 & 10 \\ \begin{array}{l}\text { Primary Care } \\ \text { Provider (PCP }\end{array} & 77.4 & 3.6 & 10.7 & 7.1 & 0 & 4.5 & 7 \\ \text { Signature items } & 80 & 6.7 & 13.3 & 0 & 0 & 4.7 & 5 \\ \text { Total } & - & - & - & - & - & - & 60\end{array}$

b) Clinical Data

\begin{tabular}{|c|c|c|c|c|c|c|c|}
\hline $\begin{array}{l}\text { Data } \\
\text { sections }\end{array}$ & $\begin{array}{c}\text { Strongly Agree } \\
(\%)\end{array}$ & $\begin{array}{c}\text { Agree } \\
(\%)\end{array}$ & $\begin{array}{c}\text { No idea } \\
(\%)\end{array}$ & $\begin{array}{c}\text { Disagree } \\
(\%)\end{array}$ & $\begin{array}{c}\text { Strongly } \\
\text { Disagree (\%) }\end{array}$ & $\begin{array}{l}\text { Average } \\
\text { rates }\end{array}$ & $\begin{array}{c}\text { Final number of } \\
\text { data elements }\end{array}$ \\
\hline Menstrual history & 81.4 & 17 & 1.6 & 0 & 0 & 4.8 & 26 \\
\hline Sexual Issues & 84 & 14.3 & 1.7 & 0 & 0 & 4.8 & 25 \\
\hline Previous reviews & 71.9 & 19.4 & 8.2 & 0.3 & 0 & 4.5 & 97 \\
\hline Previous treatment & 81 & 15.1 & 3.9 & 0 & 0 & 4.7 & 57 \\
\hline $\begin{array}{l}\text { Previous surgical } \\
\text { procedures }\end{array}$ & 83.3 & 14.8 & 1 & 0.5 & 0 & 4.8 & 32 \\
\hline $\begin{array}{l}\text { IVF / ICSI cycles / } \\
\text { or previous frozen } \\
\text { embryos transfer }\end{array}$ & 83.3 & 15.9 & 0.8 & 0 & 0 & 4.8 & 11 \\
\hline Medical history & 71.6 & 20.8 & 7.2 & 0.4 & 0 & 4.5 & 191 \\
\hline $\begin{array}{l}\text { The history of } \\
\text { medicine }\end{array}$ & 71.7 & 20.6 & 7.8 & 0 & 0 & 4.4 & 30 \\
\hline Social Issues & 80.1 & 15.2 & 4 & 0.7 & 0 & 4.7 & 23 \\
\hline Family History & 70.1 & 19.8 & 9.8 & 0.2 & 0 & 4.4 & 107 \\
\hline Pregnancy history & 72.1 & 21.6 & 6.3 & 0 & 0 & 4.5 & 32 \\
\hline Causes of infertility & 80.1 & 14.7 & 5.1 & 0 & 0 & 4.8 & 13 \\
\hline $\begin{array}{l}\text { Andrology tests in } \\
\text { men }\end{array}$ & 72.6 & 22.6 & 4.9 & 0 & 0 & 4.5 & 24 \\
\hline $\begin{array}{l}\text { Immunological } \\
\text { examination in } \\
\text { women }\end{array}$ & 67.9 & 19 & 11.9 & 1.2 & 0 & 4.3 & 7 \\
\hline $\begin{array}{l}\text { Features of the } \\
\text { cycle }\end{array}$ & 83.3 & 13.2 & 3.1 & 0.3 & 0 & 4.8 & 53 \\
\hline $\begin{array}{l}\text { Interventional } \\
\text { measures and } \\
\text { methods: Ovules, } \\
\text { fertilization } \\
\text { and embryos, } \\
\text { protocols, and the } \\
\text { type of drugs used. }\end{array}$ & 81.4 & 13.8 & 3.5 & 1.2 & 0 & 4.7 & 87 \\
\hline
\end{tabular}




$\begin{array}{lccccccc}\begin{array}{l}\text { Data } \\ \text { sections }\end{array} & \begin{array}{c}\text { Strongly Agree } \\ (\%)\end{array} & \begin{array}{c}\text { Agree } \\ (\%)\end{array} & \begin{array}{c}\text { No idea } \\ (\%)\end{array} & \begin{array}{c}\text { Disagree } \\ (\%)\end{array} & \begin{array}{c}\text { Strongly } \\ \text { Disagree (\%) }\end{array} & \begin{array}{c}\text { Average } \\ \text { rates }\end{array} & \begin{array}{c}\text { Final number of } \\ \text { data elements }\end{array} \\ \begin{array}{l}\text { Treatment results: } \\ \begin{array}{l}\text { Pregnancy and } \\ \text { childbirth }\end{array}\end{array} & 83 & 11.8 & 4.4 & 0.8 & 0 & 4.8 & 72 \\ \begin{array}{l}\text { Complications } \\ \text { Donor information }\end{array} & 80.6 & 15.7 & 3.7 & 0 & 0 & 4.7 & 9 \\ \text { Total } & 75.2 & 14.2 & 7 & 0.6 & 0 & 4.5 & 44\end{array}$

Table 3: Examples of managerial data elements for an MDS for the Infertility Monitoring System

\begin{tabular}{ll}
$\begin{array}{l}\text { Part } \\
\text { Demographic data }\end{array}$ & $\begin{array}{l}\text { Data elements } \\
\text { Clinical trial identifier, clinic name, patient's name, date of birth (age), place of birth, contact information, } \\
\text { age at the start of the treatment, race, ethnicity, marital status, duration of marriage, other }\end{array}$ \\
$\begin{array}{ll}\text { Insurance information } \\
\text { Insurance company name, patient relationship to insured (self, spouse, child, other), original patient } \\
\text { insurance, insurer, address, insurance number, expiration date, other. }\end{array}$ \\
$\begin{array}{ll}\text { Primary Care Provider } \\
\text { (PCP) }\end{array}$ & $\begin{array}{l}\text { Name, medical system number, specialty, address, phone number, e-mail. } \\
\text { Signature items }\end{array}$ \\
\hline
\end{tabular}

Clinical data elements were categorized into four parts:

Medical history: Causes of Infertility, Sexual history (Menstrual history, Sexual history), Previous Examinations, Previous Diseases, Treatments, Tests, Surgeries, Medication, Social History, Family History, and Pregnancy History.

Treatment plan: Cycle Characteristics of the Treatment, Specifications of Eggs, Embryos/Blastocyst Profile, Treatments (Medication Treatments, Techniques Used in Treatment)

Treatment results: Pregnancy and Childbirth, Complications

\section{Donor information.}

\section{Discussion}

Infertility affects over $15 \%$ of couples in reproductive age, and the prevalence of infertility in the world is increasing [13]. An accurate assessment of the prevalence and different etiologies of infertility is essential in order to plan appropriate strategies for the prevention, treatment, and management of health and socioeconomic outcomes [14]. Organizations need more comprehensive data collection and data planning in order to plan and, access to new and reliable information about the number of patients, diseases, methods and new therapeutic outcomes [10]. MDS is a tool with a variety of applications that can be implicated at the individual level in planning care and measuring outcomes and at the organizational level in quality management. MDS will facilitate comparison of data at the regional, national and international levels. The minimum data set can be dramatically used in the management of evidencebased healthcare [15].

In this study, based on the results obtained by using the Delphi technique, the majority of relevant experts agreed with the proposed model and it is considered suitable for infertility centers. Therefore, the proposed model as the final model of this research is recommended, and its implementation is recommended to infertility centers.

Various studies point to the importance of MDS in the development of information management system in different areas such as burns [9], trauma [16], biochemistry laboratories [17], antimicrobial resistance management (18), speech therapy (10), cystic fibrosis [19], C-section anesthesia [12], orthopedic injuries [20], organ transplantation [11], diabetes mellitus [21], aging [22], and echocardiography reporting system [23].

Identification of the minimum data set is the first step to standardize and integrate the data used in the diagnosis and can be useful in evaluating it [24]. MDS provides a comprehensive summary of the critical functional areas and the use of standardized definitions, and the response categories provide a common language in deciding on appropriate care plans and interventions that facilitate the assessment of multimedia teams and care planning. 


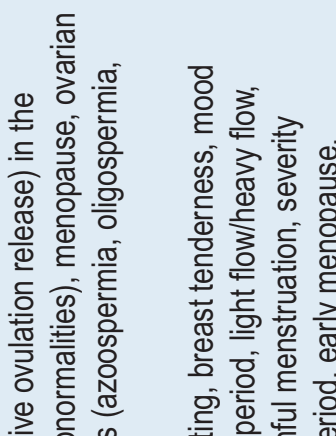

प्र

क्ष

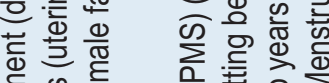

है कू है क्ञ

䠌

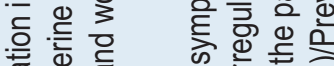

元䒓它 क क

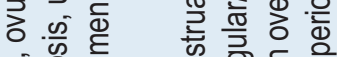

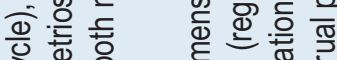

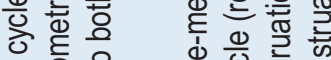

응응 융흐웡

둥 $\frac{1}{0}$

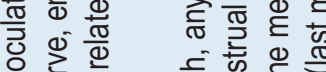

. Ф

कू

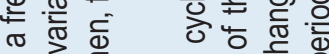

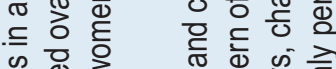

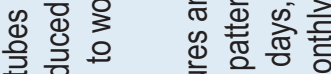

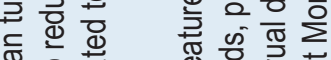

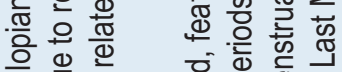

응

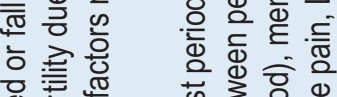

过 旁

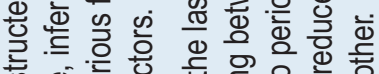

형 $\frac{1}{5}$

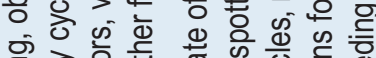

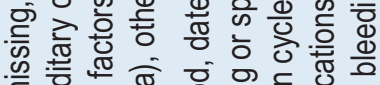

\section{है}

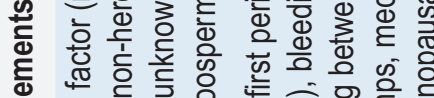

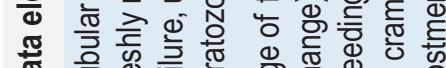

ఫे

$\frac{\infty}{2}$

$\frac{\mathbb{\Phi}}{\Phi}$

푱

정

4

$\frac{\mathscr{d}}{\text { 을 }}$

ய்

感

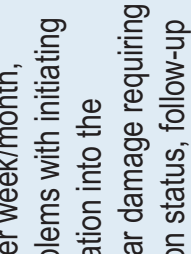

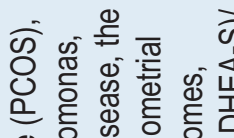

๑응 흥 응 잉

든 은 뜰 ญू

के कूष

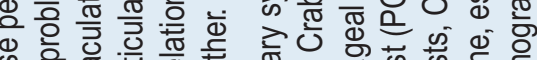

क्ष

을 की.

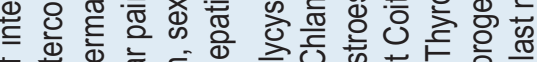

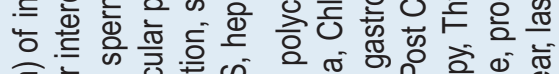

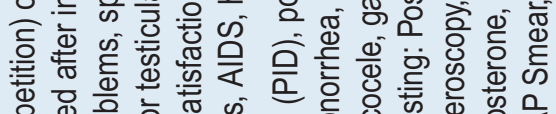

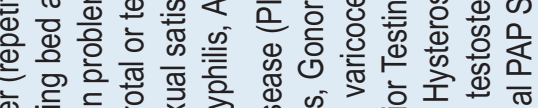

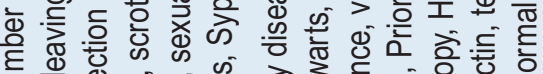

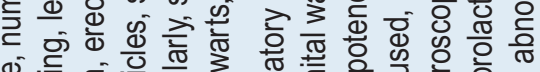

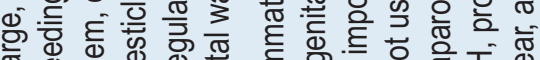

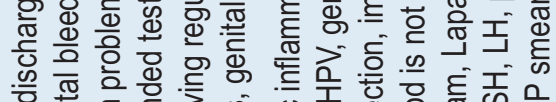

क्ष

突

高

世宁

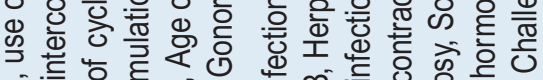

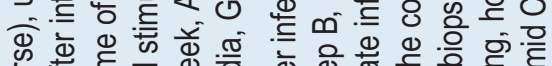

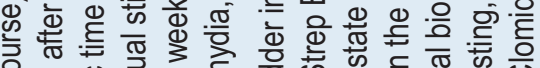

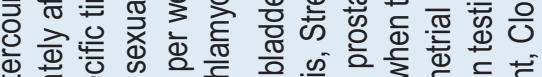

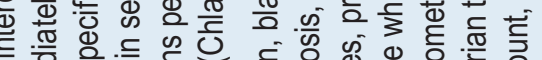

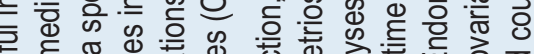

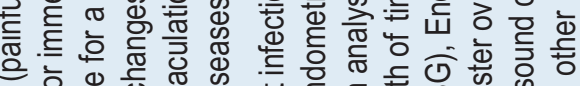

휴

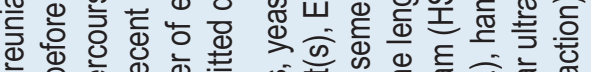

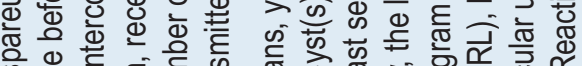

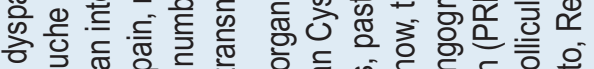

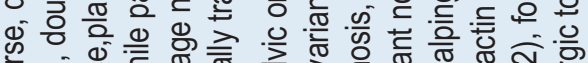
言

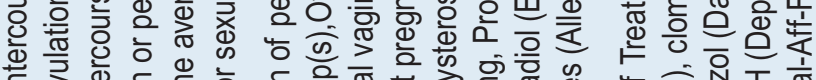

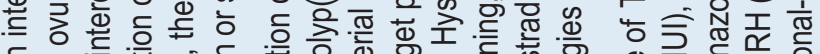

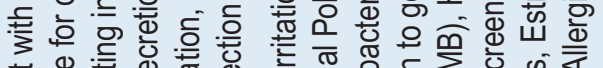

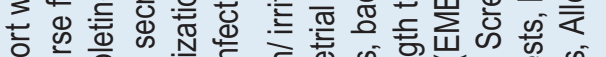

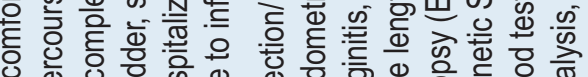

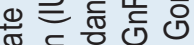
응 등 등 흥

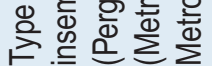

등 흄 $\frac{\infty}{\bar{D}}$

흥

청 을 음

त्ण

잉 엉

ญ 응 흥 흥

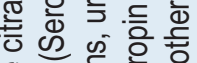

Ф

을 흔 혼혼

응 क्षे

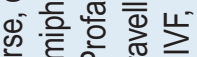

엉 음

这论

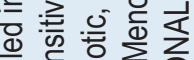

웡 를 음

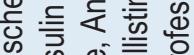

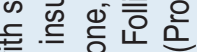

就恋

蒙㐫

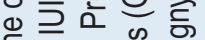

Ф

을 응 은 옿

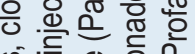

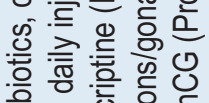

듣 들 을

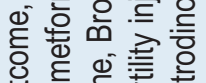

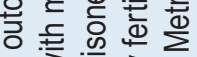

뒹 帘

है त्ञाँ

㐘 就

๘

등 응 흥 흥

틀 응난

등

응 응

들 끈

ต 空

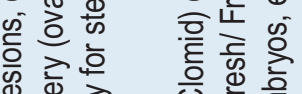

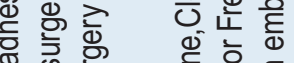

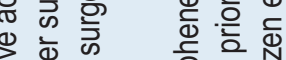

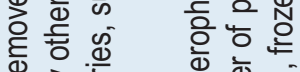

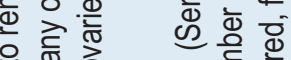

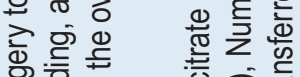

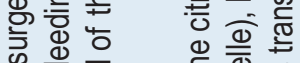

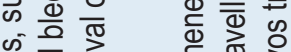

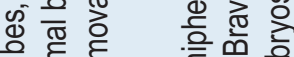

है है

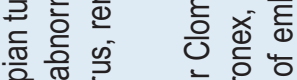

은 는 造 흔 응 힝

Ф히 흥 흘

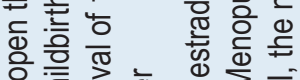

응 을

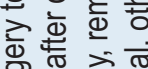

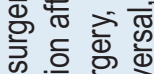

장요 믄

ㅊㅎㅇ के 응 눈

क्ञ⿰

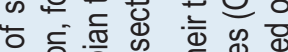

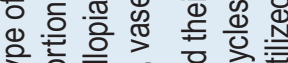

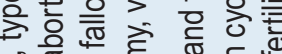

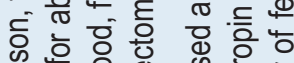

ญั

ब른 응 응

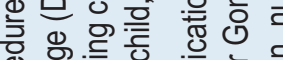

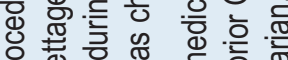

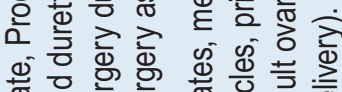

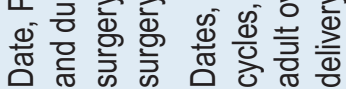

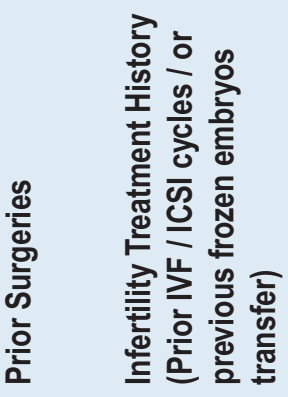




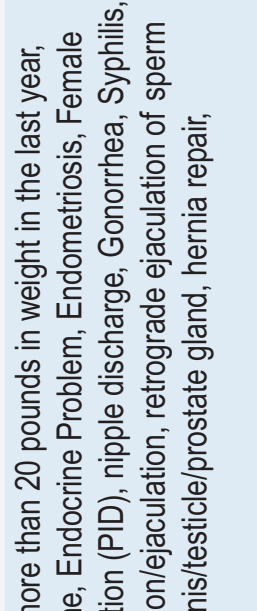

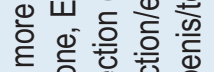

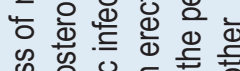

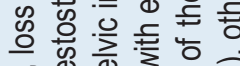
灰

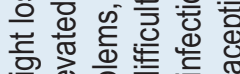

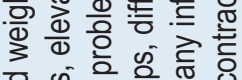

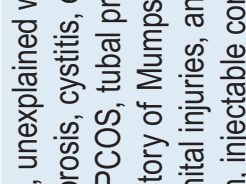

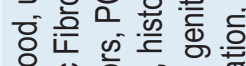

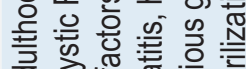

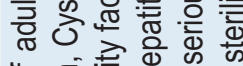

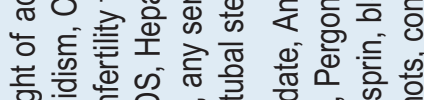

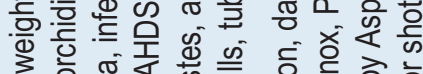

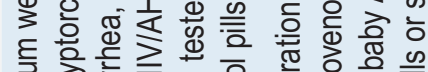

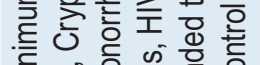

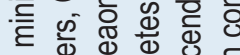

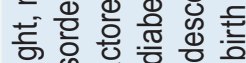

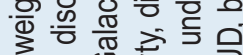
呛 西

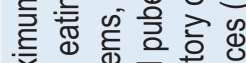

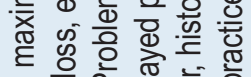
西

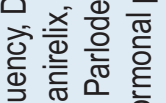

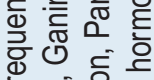

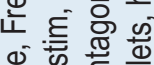

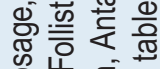

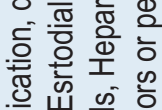

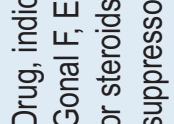

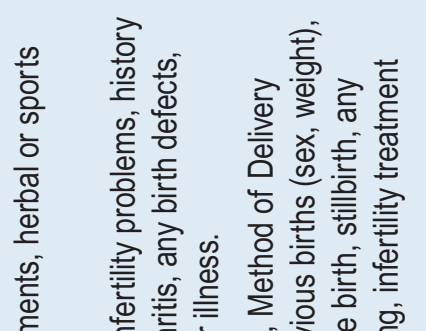

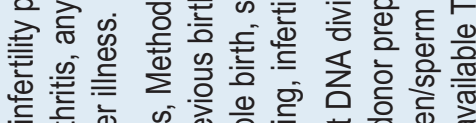

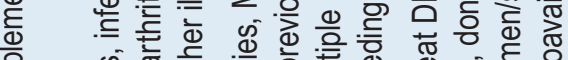

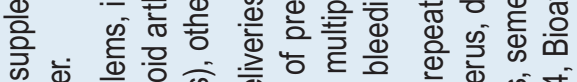
की

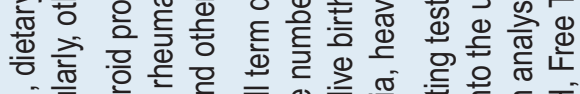

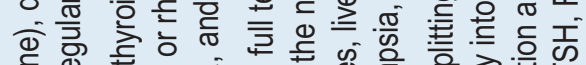
船 边 O.

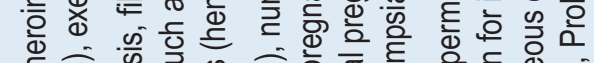

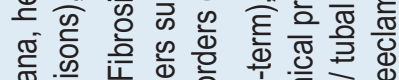

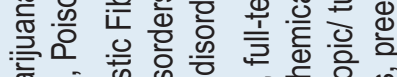

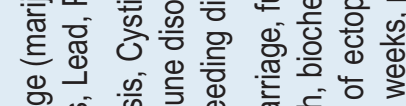

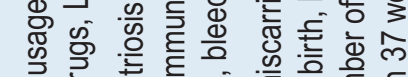

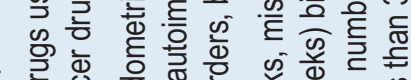

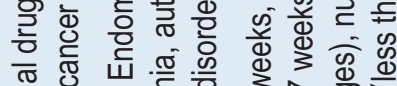

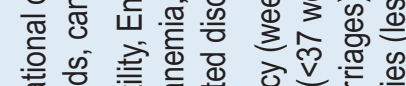

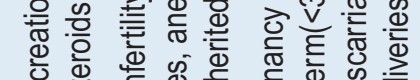

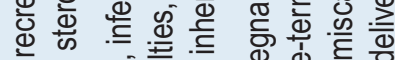

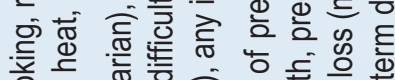

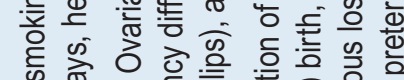

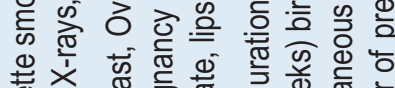
क्ष

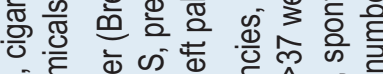

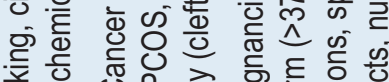

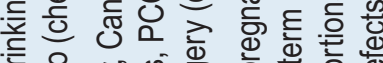

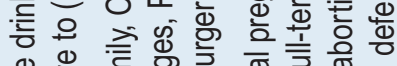

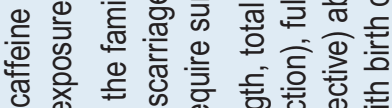
ब

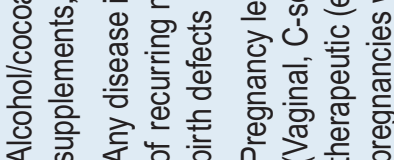

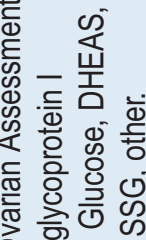

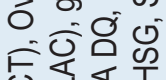
이로

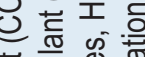

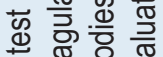
․ㅡㄹ 을

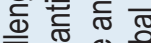

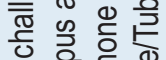
을

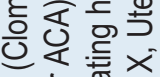
过 흘

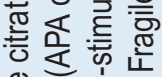

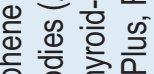
을 흘 识突过 齐举这 就

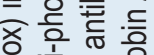
둔 过 을 表응 오 든 응 䨌

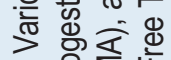
$\infty$ 은

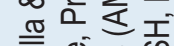

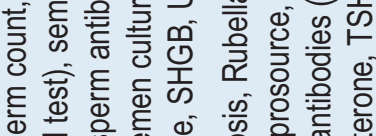

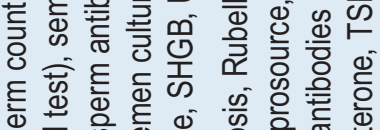
क⿺辶े क

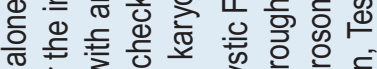
क क्षे ते का की क

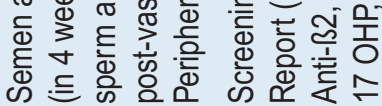

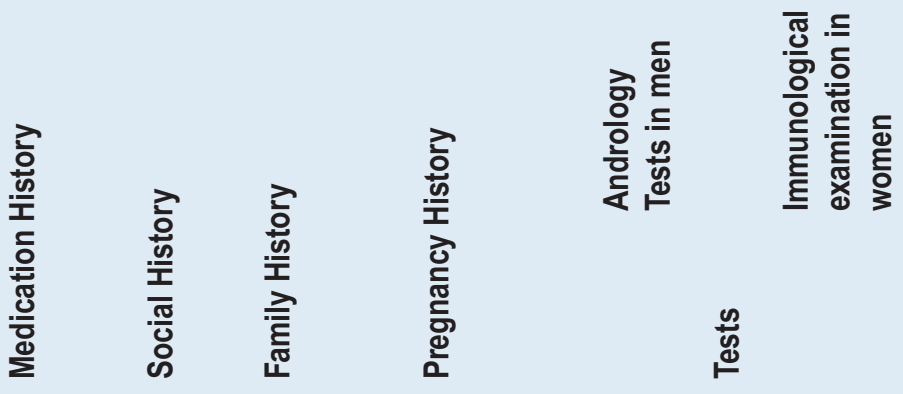




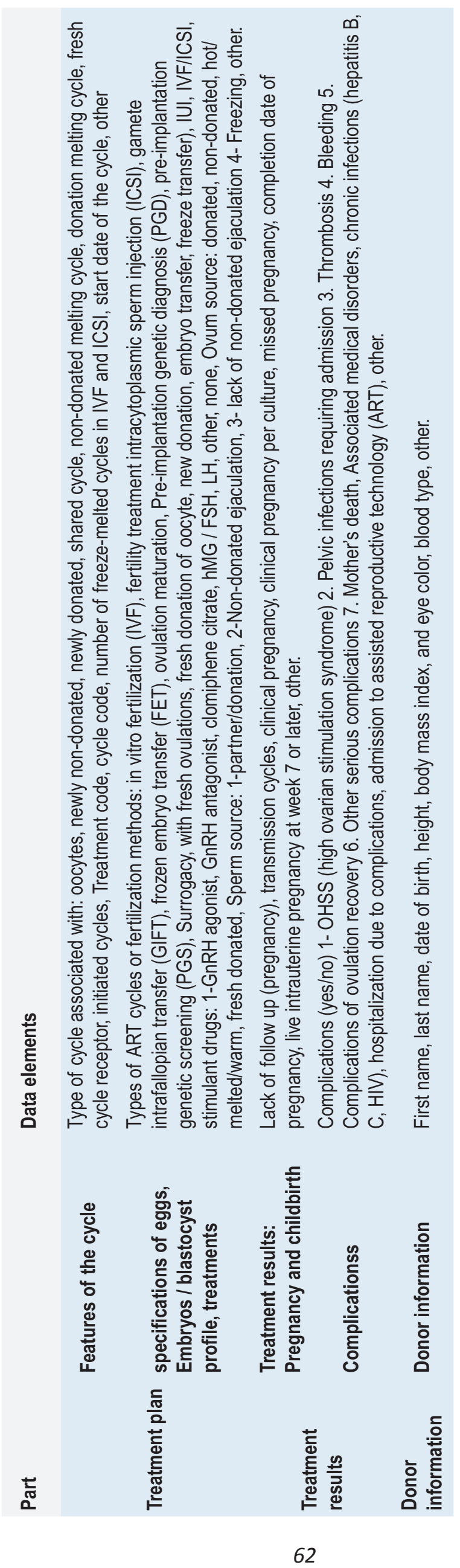


Due to reliability, MDS data can be used through the use of standardized information elements along with the same definitions and the provision of effective infertile management indicators for various purposes in addition to improving care [25]. Determining and identifying the minimum required data leads to better coordination in data collection and retrieval using information systems and allows us to identify and determine the required data [26].

\section{Conclusions}

Considering the adverse effects of infertility, designing and implementing a comprehensive and appropriate infertility data set model in centers can be an essential step in the creation of infertility monitoring system for high-quality and proper treatment, regular planning for controlling and preventing infertility, allocating credit to infertility centers and clinics and doing research. MDS helps infertility management by providing continuous care of patients, establishing a link between care providers and analyzing the effectiveness of patient care and the community of infertile patients. Through the use of MDS organized as designated forms, patient identification indicators, efficiency indicators of the care process and the quality of the services provided as well as outcome indicators, fertility management was improved. In addition, it will be possible to develop policies, prevent and control infertility and, consequently, improve the quality of care and save costs.

It is clear that an important issue in preventing infertility is having access to credible and powerful information systems such as an infertility monitoring system. Although some countries develop and implement infertility management systems, data cannot be compared correctly due to differences in data and lack of international standards. Therefore, the provision of such standards will lead to the development of these systems in other countries.

\section{Acknowledgment}

The authors would like to thank all the specialists from the Fasa University of Medical Sciences who participated or otherwise contributed to this study.

\section{Conflict of Interest}

The authors confirm that there are no conflicts of interest.

\section{References}

1. Macaluso M, Wright-Schnapp TJ, Chandra A, Johnson R, Satterwhite $C L$, Pulver $A$, et al. A public health focus on infertility prevention, detection, and management. Fertility and sterility. 2010; 93(1):16. e1-e10.

2. Mascarenhas MN, Flaxman SR, Boerma T, Vanderpoel S, Stevens GA. National, regional, and global trends in infertility prevalence since 1990: a systematic analysis of 277 health surveys. PLoS Med. 2012; 9(12):e1001356.

3. Direkvand-Moghadam A, Sayehmiri K, Delpisheh A, DirekvandMoghadam A. The global trend of infertility: an original review and meta-analysis. International Journal of Epidemiologic Research. 2014;1(1):35-43.

4. CDC. A national public health action plan for the detection, prevention, and management of infertility. Centers for Disease Control and Prevention, Atlanta, GA. 2014.

5. CDC. Key statistics from the national survey of family growth. 2013.

6. Hardee K, Gay J, Blanc AK. Maternal morbidity: neglected dimension of safe motherhood in the developing world. Global Public Health. 2012; 7(6):603-17.

7. Malhotra N, Shah D, Pai R, Pai H, Bankar M. Assisted reproductive technology in India: A 3 year retrospective data analysis. Journal of human reproductive sciences. 2013; 6(4):235.

8. Abdelhak M, Grostick S, Hanken MA. Health Information-E-Book: Management of a Strategic Resource: Elsevier Health Sciences; 2014.

9. Ahmadi M, Alipour J, Mohammadi A, Khorami F. Development a minimum data set of the information management system for burns. Burns. 2015; 41(5):1092-9.

10. Damanabi S, Abdolnejad S, Karimi G. Suggested Minimum Data Set for Speech Therapy Centers Affiliated to Tabriz University of Medical Sciences. Acta Informatica Medica. 2015; 23(4):243.

11. Karimi S, Saghaeiannejad IS, Farzandipour M, Esmaeili GM. Comparative study of minimum data sets of health information management of organ transplantation in selected countries and presenting appropriate solution for Iran. 2011.

12. Sheykhotayefeh $M$, Safdari R, Ghazisaeedi M, Khademi SH, Farajolah SSS, Maserat E, et al. Development of a Minimum Data Set (MDS) for C-Section Anesthesia Information Management System (AIMS). Anesthesiology and Pain Medicine. 2017; 7(2).

13. Naser SSA, Alhabbash MI. Male Infertility Expert system Diagnoses and Treatment. American Journal of Innovative Research and Applied Sciences. 2016; 2(4).

14. Safarinejad MR. Infertility among couples in a population-based study in Iran: prevalence and associated risk factors. International Journal of Andrology. 2008; 31(3):303-14.

15. Poss J, Jutan N, Hirdes J, Fries B, Morris J, Teare G, et al., editors. A review of evidence on the reliability and validity of Minimum Data Set data. Healthcare Management Forum; 2008: Elsevier.

16. Ghodsi Z, Movaghar VR, Zafarghandi M, Saadat S, Mohammadzadeh M, Fazel M, et al. The Minimum Dataset and Inclusion Criteria for the National Trauma Registry of Iran: A Qualitative Study. Archives of Trauma Research. 2016; 6(2).

17. Shahmoradi M, Firoozabadi SM, Mohammadzadeh N. The Local Minimum Dataset of Biochemistry Laboratory Information Systems. 2016.

18. Safdari R, Saeedi MG, Masoumi-Asl H, Rezaei-Hachesu P, Mirnia $\mathrm{K}$, Mohammadzadeh $\mathrm{N}$, et al. National Minimum Data Set for Antimicrobial Resistance Management: Toward Global Surveillance System. Iranian Journal of Medical Sciences. 2018.

19. Kalankesh LR, Dastgiri S, Rafeey M, Rasouli N, Vahedi L. Minimum data set for cystic fibrosis registry: a case study in Iran. Acta Informatica Medica. 2015; 23(1):18. 
20. Ahmadi M, Mohammadi A, Chraghbaigi R, Fathi T, Baghini MS. Developing a minimum data set of the information management system for orthopedic injuries in iran. Iranian Red Crescent Medical Journal. 2014; 16(7).

21. Jahanbakhsh $M$, Moghaddasi $H$, Hosseini A. Designing of diabetic mellitus minimum data sets: indicator basis of diabetic management effectiveness. Health information management. 2010;7(3):330-40.

22. Kowal PR, Wolfson LJ, Dowd JE. Creating a minimum data set on ageing in sub-Saharan Africa. Southern African Journal of Gerontology. 2000; 9:18-23.

23. Mahmoudvand Z, Kamkar M, Shahmoradi L, Nejad AF. Determination of Minimum Data Set (MSD) in Echocardiography
Reporting System to Exchange with Iran's Electronic Health Record (EHR) System. Acta Informatica Medica. 2016; 24(2):116.

24. Bauer J, Sieber C. Significance and diagnosis of malnutrition in the elderly. Zeitschrift fur arztliche Fortbildung und Qualitatssicherung. 2006;101(9): 605-9.

25. Hawes $\mathrm{CH}$, Morris JN, Phillips CD, Fries BE, Murphy K, Mor V. Development of the nursing home Resident Assessment Instrument in the USA. Age and Ageing. 1997; 26(suppl_2):19-25.

26. Avidan A, Weissman C. Record completeness and data concordance in an anesthesia information management system using context-sensitive mandatory data-entry fields. International Journal of Medical Informatics. 2012;81(3):173-81 